\title{
EI Niño driven haze over the Southern Malaysian Peninsula and Borneo
}

${ }^{1}$ Department of Chemistry, Faculty of Science, 50603 Kuala Lumpur, Malaysia

${ }^{2}$ School of Environment Science and Spatial Informatics, China University of Mining and Technology, Xuzhou, China

${ }^{3}$ Department of Civil Engineering, Faculty of Engineering and Built Environment, Universiti Kebangsaan Malaysia, 43600 Bangi, Selangor, Malaysia

${ }^{4}$ Earth Observation Centre, Institute of Climate Change, Universiti Kebangsaan Malaysia, 43600 Bangi, Selangor, Malaysia

${ }^{5}$ Department of Earth Sciences and Environment, Faculty of Science and Technology, Universiti Kebangsaan Malaysia, 43600 Bangi, Selangor, Malaysia

${ }^{6}$ Environmental Health and Industrial Safety Program, School of Health and Applied Sciences, Faculty of Health Sciences, Universiti Kebangsaan Malaysia, Jalan Raja Muda Abdul Aziz, 50586 Kuala Lumpur, Malaysia

${ }^{7}$ Global Centre for Clean Air Research, Department of Civil and Environmental Engineering, Faculty of Engineering and Physical Sciences (FEPS), University of Surrey,

Guildford, GU2 7XH, United Kingdom

${ }^{8}$ Department of International and Strategic Studies, Faculty of Arts and Social Sciences, University of Malaya, Kuala Lumpur 50603, Malaysia 
$24{ }^{9}$ Space Science Centre (ANGKASA), Universiti Kebangsaan Malaysia, 43600 UKM, Bangi, Selangor, Malaysia

$26{ }^{10}$ Institute of Ocean and Earth Environmental (IOES), University of Malaya, Kuala Lumpur, 50603, Malaysia

32 Abstract 
33 The Southeast Asian (SEA) region, however, is no stranger to forest fires - the region has been

34 suffering from severe air pollution (known locally as 'haze') as a result of these fires, for decades. The

35 fires in SEA are caused by a combination of natural (the El Niño weather pattern) and manmade

36 (slash-and-burn and land clearing for plantations) factors. These fires cause the emissions of toxic

37 aerosols and pollutants that can affect millions of people in the region. Thus, this study aims to

38 identify the impact of the South East Asia haze on the Southern region of the Malaysian Peninsula and

39 Borneo region of East Malaysia using the entire air quality observation data at surface level in 2015.

40 Overall, the concentration of $\mathrm{PM}_{10}$ was about two-fold higher during the haze period compared to non-

41 haze period. The concentrations of $\mathrm{CO}$, flux of $\mathrm{CO}$ and flux of $\mathrm{BC}$ were aligned with $\mathrm{PM}_{10}$ during the

42 entire observation period. The wind field and cluster of trajectory indicated that the southern

43 Malaysian Peninsula and Borneo were influenced mainly from the wildfires and the combustion of 44 peat soil in the Indonesian Borneo. This study finds that wildfires from Borneo impacted the Southern

45 Malaysian Borneo more seriously than that from Sumatra region.

46 Keywords: Aerosol; Trace gases; Haze; Wild Forest fires; Biomass burning; Peatland fires

48 Highlights

49 - The yearly average of $\mathrm{PM}_{10}$ exceeds all health guidelines during haze in 2015

$50 \quad-\quad \mathrm{CO}$ has been established well to reflect the intensity of the haze

51 - A covariation of $\mathrm{BC}$ flux with $\mathrm{CO}$ and $\mathrm{PM}_{10}$ concentrations was observed during haze Southern Malaysian Peninsula and Borneo were impacted from fires in Kalimanthan 


\section{Graphical abstract}
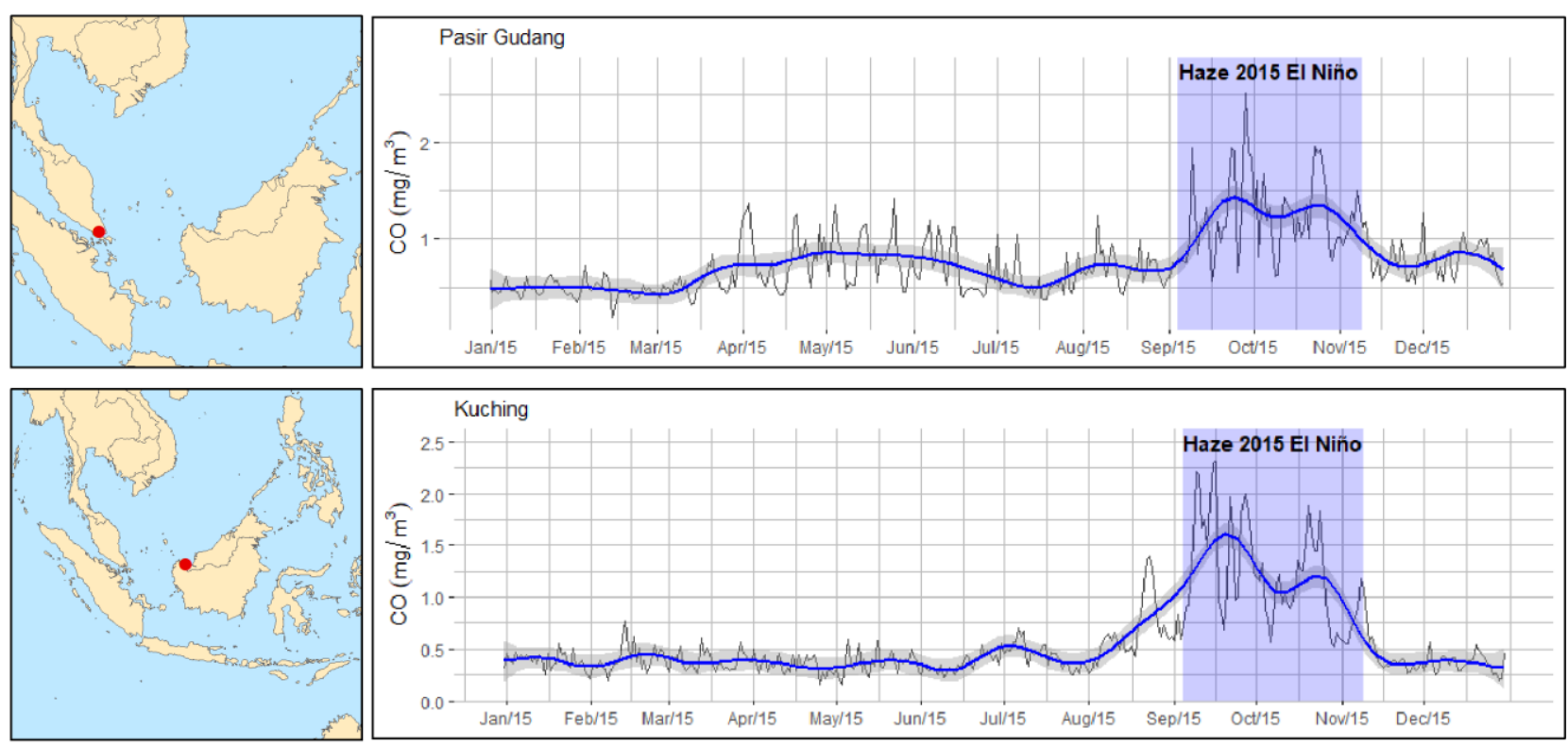

54
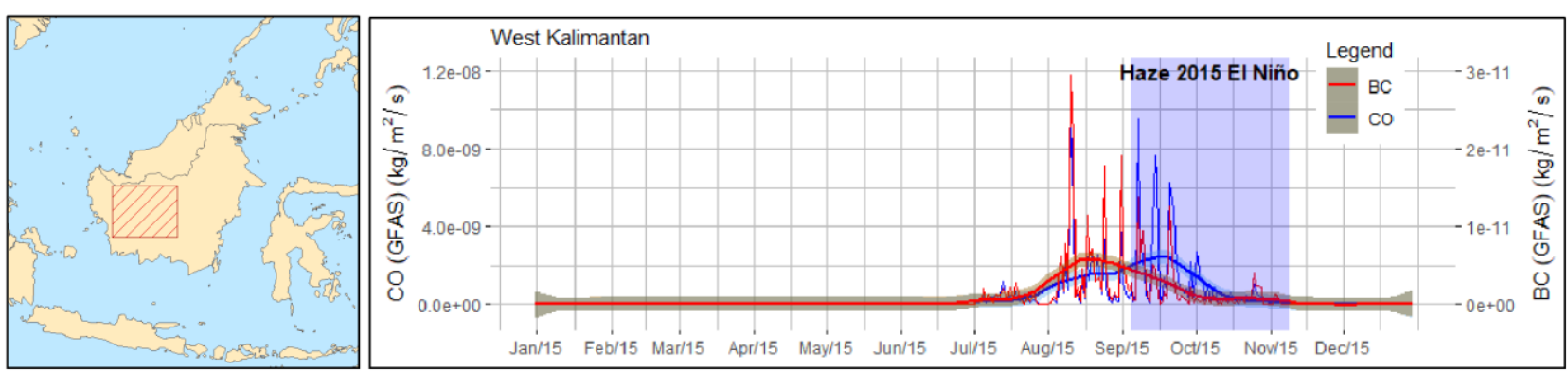

55

56 


\section{Introduction}

Urban air pollution is a serious health issue globally due to excess or premature death burden (Brauer et al., 2016; Cohen et al., 2017; WHO, 2016). According to the World Health Organisation (WHO), nine out of ten people breathe polluted air throughout the world (WHO, 2018). About 7 million deaths a year was potentially due to the exposure of ambient and household air pollution (WHO, 2018). It has been established now that air pollution is a critical risk factor for non-communicable diseases (NCDs) which leads to $24 \%$ of all adult deaths from heart-related diseases, $25 \%$ from stroke, $43 \%$ from chronic obstructive pulmonary disease and $29 \%$ from lung cancer (WHO, 2018). A recent study also showed that the exposure of air particles could cause dementia and other brain-related diseases to the people staying near urban roadways and power plants (Underwood, 2017).

In South-East Asia, air pollution has been dangerously impacted on human health, visibility, ecosystem and agricultural production (Kumar et al., 2020; Kumar et al., 2015). Haze is defined as the increased load of atmospheric aerosol which causes visibility to reduce significantly. Visibility is reduced by the absorption and scattering of light by both gases and particles in ambient air (Seinfeld and Pandis, 2016). Haze is a regional air pollution issue. In Southeast Asia (SEA), haze occurs due to the "slash and burn" activities to clear land for new plantations and to manage agricultural waste and wild forest fires which form high amounts of aerosol or black smoke (Keywood et al., 2003; Khan et al., 2016). This haze spreads over the entire SEA region and the visibility decreases due to the absorption of sunlight in the black smoke. Haze also occurs due to the formation of photochemical smog such as ozone, peroxyacetyl nitrate (PAN), etc. During conditions of high humidity with larger relative humidity ( $\mathrm{RH} \%$ ), the hygroscopic ionic composition in aerosols increase, for example sulfate, nitrate, and water vapor which are potential light scattering species which lead to reduced visibility as reported by Friedlander (2000). Haze or smoke is the potential cause of air pollution in South East 
Asia. During the haze episodes, the concentration of aerosol particles sharply increases and the ambient visibility reduces proportionally in Malaysia (Khan et al., 2016; Koe et al., 2001). The main causes of haze pollution in Malaysia are "slash and burn" activities to clear land for new plantations and to manage agricultural waste, mainly in Indonesia's Sumatra and Kalimantan regions. These activities are closely related to economically important sectors like palm oil and pulp and paper there. During previous haze episodes, it has been understood that Singapore has been impacted by the emission of air pollutants from Borneo while the Kuala Lumpur City in Malaysian Peninsula was more influenced by fire smoke of the Sumatra region (Koe et al., 2001). Thus, the wildfires in the Sumatra and Kalimantan (Indonesian Borneo) region are the potential hotspots causing the recurrence of the annual haze in this area. Peat burning has been initially ignited by the above ground biomass of forest materials above the peat soil and worsened by El Nino phenomena. In pristine condition, fire rarely occurs in peat soil due to its high moisture content as it occurs at coastal wet areas (Hope et al., 2005). However, in recent years peatlands have become more unstable and degraded due to largescale extraction to make way for agricultural developments, forestry and urban development contributing to the main cause of lowland peat soil loss (Kumar et al., 2020). Peat fires may last for days, week and even months as the fire can penetrate underneath the peat layer, making it difficult to put out and persist to smoulder, producing huge amounts of $\mathrm{CO}_{2}$ and smoke (haze) in short time (Field et al., 2016). Fires from peat soils emit a substantial amount of air particles and reactive gases in the Sumatra and Indonesian Borneo region (Jayarathne et al., 2017; Roulston et al., 2018; Stockwell et al., 2016; Wooster et al., 2018). So, a large quantity of reactive gases, aerosol and its compositions, greenhouse gases are emitted during the biomass and peatland fires.

El Niño is an inter-annual phenomenon and can intensify the wildfires in this region. The El Niño phenomenon that occurred in 2015 was another precursor for the escalated wildfire event in Southeast Asia. An El Niño condition is a non-regular occurrence in the tropical Pacific region that occurs when surface water in the equatorial Pacific becomes warmer than average and east winds blow weaker than 
normal (NOAA, 2015). An El Niño event as Nino $\mathrm{Z}$ index anomaly $\geq 0.5{ }^{\circ} \mathrm{C}$ in five consecutive months, and a strong El Niño event as Nino Z index anomaly $\geq 1{ }^{\circ} \mathrm{C}$ in five consecutive months (Zhai et al., 2016). The year 2015 was the warmest on record and a super-strong El Niño also formed that year (Zhai et al., 2016). In South-East Asia, this brings drier weather and cause drought in lots of places across the region. During dry weather, peat soil is more susceptible to fire. Thus such conditions further degrade peat soil, causing it to lose its stability and moisture. The slash and burn during this dry weather escalate fire which can spread in an uncontrollable manner. The fire will burn and smoulder in peat soil, as peat acts as fuel for the fires.

Acknowledging the role of peat fires in the haze, the Indonesian government has established various laws that prevent the unsustainable development of peatlands. These include the Indonesian Government Regulation 26/2008 and Presidential Decree 32/1990 which dictate that peat more than three metres deep should be automatically designated as protected areas, Ministry of Agriculture Regulation 14/2009 which prohibits the clearing of an entire concession if more than $30 \%$ of the concession is located on deep peat (Varkkey, 2016) and a moratorium on issuing new concession licenses to use land designated and peatland, which has been in force since 2011 and has recently been made permanent in 2019 (Jong, 2019). Despite these regulations, large areas of peatlands are regularly opened up for plantations, enabled by close, mutually reinforcing patron-client relations cultivated by elite business interests (clients) and administrative officials and politicians (patrons). These patrons often arrange for these restricted lands to be released to their clients in exchange for personal and professional kickbacks, including much needed local administrative revenue. Furthermore, with slash and burn being the cheapest technique to clear this land, some of these concessionaires do resort to this method despite it being prohibited under the Environmental Management Act No. 23/1997. The close relationship with the administrative elites often allows these concessionaires to escape prosecution for illegal land clearing and fire use, further encouraging the practice (Varkkey, 2016). In light of the studies in the literature, there is a lack of scientific link how do the natural and semi-natural wildfires 
134 alter the air quality over the Southern Malay Peninsula and Malaysian Borneo. Therefore, the present 135 study attempts comprehensively focus on the covariation of aerosol and reactive gases with respect to 136 the intensity of wildfires during the strong haze in 2015 in the Southern Malaysian Peninsula and 137 Borneo region. This study also explores the potential factors that impact on the elevated load of the 138 pollutants in these sites.

\section{Material and Methods}

\subsection{Description of the sampling site}

141 Figure S1 shows the two studied sites. These two sites will literally represent an emission level of 142 aerosols and reactive trace gases for the region. As reported in the literature, both areas are 143 significantly impacted as a result of the frequent forest fires in Indonesia (Gaveau et al., 2016; Monks 144 et al., 2015). The Pasir Gudang site in the state of Johor is located nearby Singapore and is greatly 145 influenced by industrial emissions. The main industrial settings in this city are transportation, logistics, 146 shipping industries, petrochemical activities, palm oil storage, heavy industries and refineries. The site 147 is located near the highway's transection of Pasir Gudang and Johor Bahru. Kuching in the state of 148 Sarawak in Malaysia is the capital city and the densest city in that state. The main industrial areas in 149 Kuching are Pending Industrial Estate (Mixed and Light Industries), Demak Laut Industrial Park 150 (Mixed, Light, and Medium Industries), and Sama Jaya Free Industrial Zone (Hi-Tech and Electronics 151 Industry). These industrial areas were designated by the Sarawak government to boost the city's 152 commercial and industrial activity in making it a major growth centre in East Malaysia. Apart from the

153 local emissions from industrial and anthropogenic sources, Kuching is closer to the peat-fire hotpots 154 and thus, the relative contribution of fire smoke may literally also impact the site of Pasir Gudang in 155 Peninsular Malaysia. The above considerations were carefully accounted to select the study sites.

156 With regards to land-use change detection, surface reflectance product of Landsat provided by United 157 States Geological Survey (USGS) was used, and ArcGIS and ENVI software were used to process 
satellite imageries and spatial analysis. Different land cover objects have different spectral patterns due to spectral characteristics of the materials hence, a variety of supervised classification methods has been applied and tested extensively. Maximum likelihood is one of the most popular supervised classification methods used in this study. This method is based on the probability that a pixel belongs to a particular class. It was found that much of the area of Johor and Sarawak has undergone various land-use change within about 15 years (2000-2014). The change in land use has been shown in Figure S2 and Table S1. In this study, Figure S3 shows the change in elevation over Sarawak and Johor state. Figure S4 showed the distribution of peat soil covered in this region. The gradient of the intensity in the peat soil distribution is evidently larger over the Sarawak region compared to the Southern Peninsular region. Figure 1. Shows the monthly change for the distribution of AOD at $550 \mathrm{~nm}$ over SEA in 2015. A thick of aerosol layer was evidently observed from August to September as haze episode compared to the non-haze episode plotted using the data obtained from May-June 2015.

\subsection{Observation of the data}

Observation data were secondary in nature and obtained from the Department of Environment (DOE) Malaysia. The duration and resolution of the data were from January to December 2015 and were measured on an hourly basis. The main parameters of aerosol and trace gases were $\mathrm{PM}_{10}$, carbon monoxide $(\mathrm{CO})$, ozone $\left(\mathrm{O}_{3}\right)$, sulphur dioxide $\left(\mathrm{SO}_{2}\right)$, nitric oxide $(\mathrm{NO})$, nitrogen dioxide $\left(\mathrm{NO}_{2}\right)$ and oxides of nitrogen (NOx). Wind speed (WS), wind direction (WDir), relative humidity (RH) and ambient temperature $(\mathrm{T})$ were also measured to determine the local weather pattern. $\mathrm{PM}_{10}$ and gas variables were continuously measured at the Malaysian DOE operated sites. As reported earlier by (Khan et al. (2015); Samsuddin et al. (2018)), a beta ray attenuation method used to measure $\mathrm{PM}_{10}$ (BAM 1020, Teledyne, USA). The nondispersive infrared absorption (NDIR) method was applied to monitor CO (API M300, Teledyne, USA). A florescence-based sensor was used to measure SO2 (API M100A, Teledyne, USA). Chemiluminescence is a commonly used method to measure oxides of nitrogen (NOx) and $\mathrm{O}_{3}$ (API 200A and Analyzer 400A, Teledyne, USA). As reported by Khan et al. 
183 (2015), an autocalibration was scheduled for each instrument on a daily basis. Zero air calibration as

184 well as standard cylinder gas were injected during the calibration process. A private company named 185 Alam Sekitar Sdn. Bhd. (ASMA) formerly managed the monitoring sites in Malaysia. Currently, a new 186 private company named TransWater API Sdn Bhd took over this operation and manages the sites and 187 data on behalf of the Malaysian DOE.

\subsection{Local weather variation during the measurement}

189 In this study, the transport of air mass on a monthly basis was examined using Hybrid Single-Particle 190 Lagrangian Integrated Trajectory version 4.9 (HYSPLIT 4.9) (Stein et al., 2015). The duration of the 191 backward trajectories was chosen as $120 \mathrm{~h}$ and $6 \mathrm{~h}$ intervals and initial trajectory height was 192 considered as $500 \mathrm{~m}$ and the individual backward trajectory was calculated at $0.00,0.06,12.00,18.00$ 193 UTC. To see the transboundary origin of the air mass from the mainland of China and also Indonesian 194 region, $120 \mathrm{~h}$ is suitable to cover the backward origin of the air mass. Several other studies also used $195120 \mathrm{~h}$ for the trajectory in this region (Khan et al., 2018; Samsuddin et al., 2018). Then, the cluster of the backward trajectories was obtained on monthly basis using the Window-based HYSPLIT 4.9 compiler as shown in Figures 2 and 3. The input data for HYSPLIT were obtained 198 from $\underline{\mathrm{ftp}}$ //arlftp.arlhq.noaa.gov/pub/archives/reanalysis. To determine the change in the wind vector in 199 the SEA region, a vector field was generated using the Grid Analysis and Display System (GrADS). 200 Wind vector and planetary boundary layer height (PBL) data were downloaded from the European 201 Centre for Medium-Range Weather Forecasts (ECMWF) website. The data resolution was $0.25^{\circ} \times$ $0.25^{\circ}$ for the period of January to December 2015 in the domain of SEA region as shown in Figure S5. The Global Fire Assimilation System (GFAS) emissions data as netCDF format was downloaded from the ECMWF website using python script (https://apps.ecmwf.int/datasets/data/cams-gfas/). The 205 domain of latitude +0.87 to -2.06 and longitude 110.31 to 114.01 and -3.5 to 0.77 of latitude and 100.8 to 104.9 of longitude were chosen to represent the predominant fires in West Kalimantan and Sumatra, respectively. A similar of gridbox data for PBL was also resampled Then, the gridded data with a $0.5^{\circ}$ 
$\times 0.5^{\circ}$ resolution from 01 January to 31 December 2015 as daily data at 00.00 UTC was analysed, 209 using averaging functions in the climate data operator (CDO). The data summary statistics, backward 210 trajectories and time-series figures were performed by using R software version 3.4.2 (R Development

211 Core Team, 2008). The monthly magnitude of the wind vector is shown in Figure S5. The radiative 212 fire forcing was demonstrated in Figure S6. The black carbon (BC) flux and CO flux received from 213 GFAS of ECMWF represent the intensity of the forest fire in 2015 in West Kalimantan region.

\section{$214 \quad 3 . \quad$ Results and Discussion}

\section{$215 \quad 3.1 \quad$ Geographical Background}

216 Table S1 shows the land-use change for Johor from the year 2000 to 2014 and for Sarawak, in the year 217 2000. For Johor, built-up and cropland shows an increasing percentage from $1 \%$ to $6.6 \%$ and $55.8 \%$ to $21870.9 \%$, respectively. Forest, wetland and water shows decreasing percentage from $32.7 \%$ to $19.2 \%$, $2198.9 \%$ to $2.7 \%$ and $1.6 \%$ to $0.6 \%$, respectively. Percentage of land use in Johor for development has increased from $56.8 \%$ to $77.5 \%$ and the natural resources have decreased from $43.3 \%$ to $22.5 \%$ over

22115 years. The distribution of land use in Johor shows an increase in built-up at the developing cities especially near to the port. The elevation of the land at Johor in Figure S3a shows that Johor is mostly made up of lowland. This has made the development for build-up areas and croplands much easier to be expanded. Blessed with the fertile soil of peat at low land as seen in Figure S4, Johor now a days is the largest contributor to the agricultural gross domestic product in Peninsular Malaysia (Pakiam, 2018) where the crops produced are mainly palm oil followed by rubber, vegetables and fruits. For Sarawak, the year 2000 shows the land use for development account about $33 \%$ which consist of builtup $0.1 \%$ and cropland $32.9 \%$ (Table S1). Sarawak's natural resources accounted at $67 \%$ which are consist of forest $57.9 \%$, wetland $9 \%$ and water $0.1 \%$. Data for land-use change in Sarawak was not 230 available for the year 2014. The elevation of the land at Sarawak in Figure S3b shows that Sarawak 231 has high elevation land near its border with Kalimantan. The low land area near to the sea is enriched with peat soil as shown in Figure $4 \mathrm{~b}$ and most of the development and cropland took at that place. 
233 Based on the development at Sarawak and Johor especially at the chosen site which is Pasir Gudang 234 and Kuching, local emission was already in existence and the deteriorated air quality was observed at 235 the study sites. The rain forest coverage in the Malaysian region has changed in the last decades 236 (Gaveau et al., 2016; Keywood et al., 2003; Seinfeld and Pandis, 2016). Relatively the rain forest 237 coverage in Sarawak is higher than that in Johor which is significant to the emission of biogenic 238 organic compounds at the study sites. Studies in the literature showed that the biogenic organic 239 compounds particularly isoprene and monoterpene impacts potentially as the precursor gases to the 240 ozone build up at the surface level in the presence of sunlight (Friedlander, 2000; Kumar et al., 2019;

241 Monks et al., 2015). Such factor alone could not cause severe haze and a load of pollutants are 242 observed to be carried from other transboundary sources as discussed below.

$243 \quad 3.2 \quad$ Time series of aerosol and trace gases

244 Table 1 shows the overall yearly average of $\mathrm{PM}_{10}$, trace gases and meteorological factors. Some of the 245 key variables were $\mathrm{PM}_{10}, \mathrm{CO}$ and $\mathrm{NO}$ representing mainly the biomass burning and combustion of 246 fossil fuel from the transportation sector. For the Pasir Gudang site, the yearly average concentration 247 of $\mathrm{PM}_{10}$ was $64.90 \mu \mathrm{g} / \mathrm{m}^{3}$ ranging from 11.00 to $446.0 \mu \mathrm{g} / \mathrm{m}^{3}$ while the concentration of CO was 0.78 $248 \mathrm{mg} / \mathrm{m}^{3}$ with a range of 0.023 to $4.66 \mathrm{mg} / \mathrm{m}^{3}$. NO as a proxy for the fuel combustion by the traffic 249 source was $10.31 \mu \mathrm{g} / \mathrm{m}^{3}$ ranging from 1.25 to $188.8 \mu \mathrm{g} / \mathrm{m}^{3}$. The $\mathrm{SO}_{2}$ concentration was $11.17 \mu \mathrm{g} / \mathrm{m}^{3}$ 250 with a range of 2.62 to $133.6 \mu \mathrm{g} / \mathrm{m}^{3}$. The concentration of $\mathrm{PM}_{10}$ exceeded the Malaysian air quality 251 standard (IT2-2020). From Figure 4, the time-series of the pollutants was shown during the entire year 252 of 2015. The concentration of $\mathrm{PM}_{10}$ and $\mathrm{CO}$ abruptly increased during September and October in 2015 253 compared to the other months. However, $\mathrm{O}_{3}$ has shown no significant change during the haze period. 254 We noticed that there were small spikes for $\mathrm{SO}_{2}$ and $\mathrm{NO}_{2}$ during September and October. The $\mathrm{RH}$ 255 level was relatively lower in this span of time fully representing that it was a dry monsoon. During this dry haze period, the small surge of $\mathrm{SO}_{2}$ and $\mathrm{NOx}$ is possibly due to the emissions originating from 
local industry and traffic, and a relatively reduced mixing depth turns the local air quality worse in this 258 regard.

259 From Table 1 for the Kuching site, the $\mathrm{PM}_{10}$ yearly average was $50.50 \mu \mathrm{g} / \mathrm{m}^{3}$ with a range from 5.00 $260 \mu \mathrm{g} / \mathrm{m}^{3}$ to $612.0 \mu \mathrm{g} / \mathrm{m}^{3}$ and $\mathrm{CO}$ was $0.57 \mathrm{mg} / \mathrm{m}^{3}$ with a range from $0.03 \mathrm{mg} / \mathrm{m}^{3}$ to $3.74 \mathrm{mg} / \mathrm{m}^{3}$. The 261 yearly average of gaseous pollutants $\mathrm{NO}, \mathrm{SO}_{2}$ and $\mathrm{O}_{3}$ were $4.41 \mu \mathrm{g} / \mathrm{m}^{3}$ with range from $1.25 \mu \mathrm{g} / \mathrm{m}^{3}$ to $26277.50 \mu \mathrm{g} / \mathrm{m}^{3}, 3.81 \mu \mathrm{g} / \mathrm{m}^{3}$ with range from $2.62 \mu \mathrm{g} / \mathrm{m}^{3}$ to $23.58 \mu \mathrm{g} / \mathrm{m}^{3}$ and $24.30 \mu \mathrm{g} / \mathrm{m}^{3}$ with range from $2632.00 \mu \mathrm{g} / \mathrm{m}^{3}$ to $146.0 \mu \mathrm{g} / \mathrm{m}^{3}$, respectively. The concentration of $\mathrm{PM}_{10}$ for Kuching site at $50.50 \mu \mathrm{g} / \mathrm{m}^{3}$ 264 exceeded the Malaysian air quality standard (IT2-2020) of $40.00 \mu \mathrm{g} / \mathrm{m}^{3}$. From Figure 5, the time-series 265 of the pollutants at the Kuching site in the year 2015 was presented. $\mathrm{PM}_{10}$ and $\mathrm{CO}$ show a distinct 266 trend from August to October with significant increases in the number of the pollutant's concentration. $267 \mathrm{O}_{3}$ shows a slight concentration was added during August and October while a slight drop of the 268 concentration was observed in September. $\mathrm{SO}_{2}$ and $\mathrm{NO}$ do not show significant changes in the trend. $269 \mathrm{NO}, \mathrm{NOx}$ and $\mathrm{SO}_{2}$ are significantly important proxy variables for government's intervention to 270 manage local air quality. NO and NOx demonstrated relatively higher concentrations during April271 May 2015 which play key roles in titration of $\mathrm{O}_{3}$ as seen in Figure 4. At the same time, surface ozone 272 build up was also seen during August - September which might potentially link to the higher 273 emissions of $\mathrm{CO}, \mathrm{NOx}$, biogenic volatile organics and strong warming conditions as described in the 274 literature (Geng et al., 2011; Kumar et al., 2019; Monks et al., 2015; Wennberg et al., 2018). SO 275 showed higher value during August -September 2015 which possibly originates from local industrial 276 emissions under a reduced mixing depth during haze in Malaysia. However, the variability of the 277 above parameters was not potentially significant in the Borneo site..

\section{$278 \quad 3.3 \quad$ Variation of concentrations during haze and non-haze}

279 Tables 2 and 3 showed the descriptive statistics of the observation data during the haze episodes in 2802015 and non-haze period, respectively for Pasir Gudang and Kuching. Observation at the Pasir 281 Gudang site, the level of $\mathrm{PM}_{10}$ was $61.94 \mu \mathrm{g} / \mathrm{m}^{3}$ during the non-haze which was increased two-fold 
282 during the strong haze episode in 2015. The median value of $\mathrm{PM}_{10}$ as $110.5 \mu \mathrm{g} / \mathrm{m}^{3}$ was higher 283 compared to the non-haze period. This abrupt change was also noticed during the haze episode in 284 September-October 2015 as demonstrated in Figure 4. The $\mathrm{NO}$ and $\mathrm{NO}_{2}$ were less influenced due to 285 the haze strike. The $\mathrm{NO}$ and $\mathrm{NO}_{2}$ are of short-residence time and play as potential in $\mathrm{O}_{3}$ chemistry. As 286 explained in the earlier section, $\mathrm{NOx}, \mathrm{CO}$, and biogenic VOCs are precursors to enhance $\mathrm{O}_{3}$ under 287 tropical warming atmospheric condition as suggestion in the literature (Geng et al., 2011; Kumar et al., 288 2019; Wennberg et al., 2018). However, the CO level was two times higher during haze compared to 289 non-haze. Thus, it was clearly shown that $\mathrm{PM}_{10}$ and $\mathrm{CO}$ were emitted sporadically due to the biomass 290 and peat soil burning in 2015. According to the EDGAR emissions inventory, the major emission 291 sources of $\mathrm{SO}_{2}$ are electricity and power generation (59\%), industry and construction (25\%), road 292 transportation (8\%) and residential and other sectors (6\%) (EDGAR, 2016). Thus, $\mathrm{SO}_{2}$ did not 293 demonstrate any significant change during the haze and non-haze period although there was a small 294 spike of $\mathrm{SO}_{2}$ during the haze period. As reported in the previous section, this dry monsoon increases 295 the fires spreading into soil particularly peatland which helps to accumulate more air particles and 296 reactive gases to accumulate in the ambient air over this region.

297 From Figure 8, it shows that the PBL height at both the fire hotpots in West Kalimantan and Sumatra 298 were relatively higher during the haze period starting from September to October compared to other 299 months. Thus, PBL does not influence the limit of transport of the pollutants from the fire region to the 300 study sites.. The concentration of $\mathrm{PM}_{10}$ started decreasing from December until April as this is the wet 301 season in Malaysia and experiences the largest frequency of rainfall or precipitation. Aldrian and Dwi 302 Susanto (2003) described that the moist air transported from the South China Sea can help to reduce 303 the impact of haze during the northeast monsoon. However, these do not happen due to El Nino 304 phenomenon takes place which pushes drier air to the Southeast Asia region.

305 Observation at the Kuching site for $\mathrm{PM}_{10}$ during haze shows the concentration was at $97.68 \mu \mathrm{g} / \mathrm{m}^{3}$ that 306 is three times higher than the concentration during the non-haze episode. The gaseous pollutant CO 
307 also shows an abrupt increase of three-fold concentration at $1.06 \mathrm{mg} / \mathrm{m}^{3}$ compared to the non-haze

308 period at $0.36 \mathrm{mg} / \mathrm{m}^{3}$. Among the pollutants generated from peat soil burning, $\mathrm{CO}_{2}$ and $\mathrm{CO}$ were found 309 to be the dominant elements released into the air due to high organic compound (Langmann et al., 310 2009; Stockwell et al., 2015; Yokelson et al., 1997) and particulate matter was the next highest 311 element after $\mathrm{CO}_{2}$ and $\mathrm{CO}$ from peat soil burning (Blake et al., 2009). Peat undergoes smoldering 312 combustion in the tropical region. As suggested by $\mathrm{Hu}$ et al. (2018) smoldering combustion is the 313 slow, low temperature, flameless burning of porous fuels and is the most persistent type of combustion 314 phenomena which enables peat to burn or char. Smoldering is the dominant combustion phenomena in 315 megafires in natural deposits of peat and coal which are the largest and longest burning fires on earth. 316 This phenomenon has great potential to emit a substantial quantity of aerosols, $\mathrm{CO}$ and $\mathrm{CO}_{2}$ as 317 reported in the literature (Malaysia-DOE, 2019b; Stockwell et al., 2015; Yokelson et al., 1997). O3 318 during the haze period was $31.12 \mu \mathrm{g} / \mathrm{m}^{3}$ and shows a slight increase than during non-haze averaged 319 concentration of $20.11 \mu \mathrm{g} / \mathrm{m}^{3} . \mathrm{SO}_{2}$ and $\mathrm{NO}$ do not show an apparent change in the concentration value 320 during haze and non-haze period.

\section{$321 \quad 3.4 \quad$ Factors influencing the concentrations}

$322 \quad 3.4 .1 \quad A$ monthly change in wildfire radiative power, $\mathrm{BC}$ and $\mathrm{CO}$ over SEA in 2015

323 Figure S6 shows a monthly change in wildfire radiative power over SEA in 2015 where forest fire 324 radiation force (FRP) measures the radiant energy released per time unit by burning vegetation 325 (Wooster et al., 2005). The FRP over SEA was observed to have obvious small spark starting July 326 where small yellow dotes were seen at Sumatra region representing 1 to $2\left(\mathrm{~W} / \mathrm{m}^{2}\right)$. In August, FRP was 327 observed at both Sumatra and Kalimantan region with darker yellow colour plotted and be regarded as 3282 to $3 \mathrm{~W} / \mathrm{m}^{2}$. The FRP was at its peak during September where red dotes presenting high FRP between 3295 to $9 \mathrm{~W} / \mathrm{m}^{2}$ was detected at Sumatra and Kalimantan, and then reduced in October and no significant 330 FRP was observed in November. Figures 6 and 7 show the monthly distribution of black carbon (BC) 331 and carbon monoxide (CO) fluxes over the SEA in 2015. They have an almost similar pattern, where 
332 both BC and CO starts in June at Sumatra and expanding to Kalimantan in July. BC keep increased in 333 August and at its peak in September while the month of October and November shows a gradual drop.

$334 \mathrm{CO}$ was at its peak in August and have a steady reduction starting from September to November. 335 Additionally, from Figure 6 and Figure 7 for BC flux and CO flux during the 2015 haze, it shows that 336 the strength of the emission flux of these two variables was potentially visible in the west of Borneo 337 and Sumatra region. As seen from Figure 8 of CO flux in West Kalimantan vs Sumatra, the emission 338 of CO flux in Kalimantan was about 6-7 times higher in strength that at Sumatra during the fire 2015.

339 Thus, the study sites are more impacted from the fire events in Kalimantan areas compared to Sumatra 340 in the 2015 haze in Malaysia. This is further to the surge of FRP in the month of September and 341 October 2015 (Figure S6) which clearly links to the $\mathrm{O}_{3}$ build-up in the study sites. As discussed in the 342 previous section, the prevalence of $\mathrm{O}_{3}$ occurs under a warming condition in the presence of biogenic 343 organic precursors (Monks et al., 2015). As such, $\mathrm{O}_{3}$ concentrations showed higher at both study sites 344 during haze which is possibly due to the elevated FRP in the hotspots regions..

\subsubsection{Wind vector over the entire SEA in 2015 and air mass movement}

346 Figure S5 shows the monthly change in the monsoonal wind velocity over Southeast Asia in 2015. 347 From January to March, the wind velocity strongly blows from South China Sea direction for both 348 locations at Southern site, Pasir Gudang and Borneo site, Kuching. The month of April show a slight 349 change in the direction of wind velocity for Kuching site, the wind was blown from the Kalimantan region. Starting May to October, the wind was shown blowing from Kalimantan region and the Java

351 Sea for both Pasir Gudang and Kuching with a strong wind in July to September.

352 Figure 2 shows the transport of air mass during 2015 at Pasir Gudang site. It was transported from the 353 mainland of China and the South China Sea during December, January and February. Then, the air 354 mass moved slightly to the Philippine region before arriving at the current Pasir Gudang location 355 during March and April. During May and June, we observed that air mass was from South Sumatra, 356 Indonesian Borneo and the Java Sea. The dominant air mass was from the Jakarta and Indonesian 
357 Borneo region during July while it was travelling over the Java Sea in August and September. The 358 backward trajectory was shifted and split significantly in October. The dominant air mass was from the 359 Philippine region while about 30\% frequency of the backward trajectories were from the Borneo 360 region. About 52\% frequency of the trajectories were influenced by localized sources while $48 \%$ of 361 them was from the maritime region in the South China Sea. The vector of the wind field was 362 visualized in Figure S5. The flow pattern of the wind in this region is consistent with the transport of 363 air mass from January to December 2015. Thus, the Indonesian Borneo is likely to have more 364 influence over the concentration of $\mathrm{PM}_{10}$ and $\mathrm{CO}$ at this site in Southern Peninsula Malaysia compared 365 to the biomass burning in the Sumatra region. After comparing the level of impact using $\mathrm{PM}_{10}$ as a 366 proxy in this case, the impact of haze from Borneo was more severe than that from the Sumatra region 367 of Indonesia. This finding is informative for policy development and assistance strategies for 368 Malaysia. Previously, it was understood that the haze affecting Peninsula Malaysia was generally 369 originating from the Sumatra region of Indonesia, specifically the Riau province. This understanding 370 was, for example, central in the decision of the Malaysian government to 'adopt' Riau under the 371 ASEAN Adopt-A-District Program, a five-year memorandum of understanding which involved 372 Malaysia providing community training and capacity-building projects, peatland rehabilitation 373 assistance, and haze early warning system in the province, in the hope that such improvement of 374 conditions on the ground in Riau would translate to reduced haze in Peninsula Malaysia (Varkkey, 375 2016). With this new finding, the Malaysian government may need to re-target assistance to Malaysia 376 to be more aligned towards provinces in Kalimantan in Indonesian Borneo.

377 Figure 3 shows the backward trajectory of air mass plotted for Kuching Sarawak in the year 2015. In 378 January and February, the air mass cluster came from the East China Sea near Taiwan and Luzon 379 Island, Philippines. March and April showed the air mass blowing from Palawan Island, Philippines 380 and the Philippine Sea. The air mass cluster split into three significant directions coming from Central 381 Kalimantan, Karimata Straits and the South China Sea near the Kuching site. It was observed in June 
and July, Kuching received most of the air mass flowing from Central Kalimantan, West Kalimantan and the Java Sea. The haze occurred starting from August 2015 to September 2015 as reported in the Chronology of Haze Episodes in Malaysia by the Official Portal of Department of Environment Malaysia (Malaysia-DOE, 2019a). In August, the largest percentage of air mass flow was from West Kalimantan at $46 \%$ frequency, followed by $37 \%$ frequency of air mass coming from Central Kalimantan and the least air mass came from the Java Sea at a rate of 17\% frequency. In September the dominant air mass was from Java Sea 46\% frequency, West Kalimantan $41 \%$ frequency and a small portion of $6 \%$ frequency from the region of Brunei. During October, the airflow received the large contribution from West Kalimantan, a medium portion from the sea in the direction of the North from Kuching and the least air mass from the sea near Sabah region. The air mass was observed to move from the South China Sea near East Malaysia during November. In December, the dominant air mass flowed from the South China Sea near Sarawak state, the Philippines Sea and China mainland. From the backward trajectory plot during the haze episode of August 2015 to September 2015, Central Kalimantan, West Kalimantan and the Java Sea contributed a significant portion of air mass flowing to Kuching state.

Overall, the knowledge perceived from the synoptic velocity of wind vector for the entire study period in 2015 is that moist water vapor is transported from the marine region during December to March and dry air is transported around the study sites from June to October 2015. This pattern coincides broadly with each month of the transport of air back from the backward trajectories to the study sites. When air mass is transported from the maritime region, air quality parameters particularly $\mathrm{PM}_{10}$ started decreasing. Interestingly, dry air mass is dominantly transported from the Borneo mainland and partly from the Sumatra region, which are potential causes of the spike of $\mathrm{PM}_{10}$ concentration at both study sites. 


\section{Conclusion}

407 The observation data presented in this representing Johor region, a southern Malaysian Peninsula and 408 nearby to Singapore and another site in Kuching, Malaysian Borneo. The yearly average concentration 409 of $\mathrm{PM}_{10}$ was $64.85 \mu \mathrm{g} / \mathrm{m}^{3}$ ranging from 11.00 to $446.0 \mu \mathrm{g} / \mathrm{m}^{3}$ while the concentration of CO was 0.77 $410 \mathrm{mg} / \mathrm{m}^{3}$ with a range of 0.023 to $4.66 \mathrm{mg} / \mathrm{m}^{3}$. The concentration of $\mathrm{PM}_{10}$ exceeded the Malaysian air 411 quality standard (IT2-2020) while CO and other trace gases are at a safe level. A comparison of the 412 observation data was made during haze and non-haze period in 2015 and the results showed that the 413 level of $\mathrm{PM}_{10}$ was $61.94 \mu \mathrm{g} / \mathrm{m}^{3}$ during the non-haze period which was increased by two-fold during the 414 strong haze episode in 2015. The median value of $\mathrm{PM}_{10}$ as $110.5 \mu \mathrm{g} / \mathrm{m}^{3}$ was higher compared to the 415 non-haze period. For Kuching site, the $\mathrm{PM}_{10}$ yearly average was $50.50 \mu \mathrm{g} / \mathrm{m}^{3}$ with a range from 5.00 $416 \mu \mathrm{g} / \mathrm{m}^{3}$ to $612.0 \mu \mathrm{g} / \mathrm{m}^{3}$ and CO was $0.57 \mathrm{mg} / \mathrm{m}^{3}$ with a range from $0.03 \mathrm{mg} / \mathrm{m}^{3}$ to $3.74 \mathrm{mg} / \mathrm{m}^{3}$. The 417 concentration of $\mathrm{PM}_{10}$ for Kuching exceeded the Malaysian air quality standard (IT2-2020) of 40.00 $418 \mu \mathrm{g} / \mathrm{m}^{3}$. It was observed that the pollutants at these locations were more impacted by fire events in 419 Indonesia's Sumatra and Borneo. However, the southern part of the Malaysian peninsula was impacted mainly from the biomass burning and the combustion of peat soil from the Indonesian Borneo region.

421 Further, BC flux and CO flux during the haze in 2015 showed that the strength of the emission flux of 422 these two variables was potentially visible in the west of the Borneo and Sumatra regions which 423 impacted at the study sites. Particularly, CO flux was observed about 6-7 times higher in West 424 Kalimantan compared to that in Sumatra in the 2015 haze which is a clear evidence that the study sites are more impacted from the emission received from Kalimantan.. This finding is important in informing future local and foreign policy and diplomatic assistance decisions of the Malaysian 427 government in response to external haze. A better understanding of the directional source of haze 428 affecting Malaysia will allow the Malaysian government to offer more targeted assistance to the 429 Indonesian government at both the bilateral and regional (ASEAN level) so that assistance targeted to 430 specific source provinces in Indonesia can be translated to a maximum reduction of haze severity in 
431 Malaysia during future episodes. It will also inform a more targeted and improved local fire prevention 432 strategy. A well-planned management of the land use in Sarawak and peninsular Malaysia can help 433 build national resilience against wild forest fires..

\section{Acknowledgement}

436 This research is supported by University of Malaya Research Grant IIRG009A-2019, Fundamental 437 Research Grant Scheme (FRGS) FP099-2019A, and Equitable Society Research Cluster (ESRC) 438 research grant GC003B-17SBS. The fire hotspots data were downloaded from the National 439 Aeronautics and Space Administration Land Atmosphere Near real-time Capability for Earth 440 Observing System Fire Information for Resource Management System fire archive (link: 441 https://firms.modaps.eosdis.nasa.gov/ download/). The data of the HYSPLIT model were available at $442 \mathrm{ftp} / / /$ arlftp.arlhq. noaa.gov/pub/archives/reanalysis. We received the assimilated Tera/Aqua MODIS 443 AOD data from the Copernicus Atmosphere Monitoring Service (CAMS) in the ECMWF website. We 444 acknowledge the Malaysian Department of Environment (DOE) for maintaining a network of stations 445 that provide continuous air quality measurements across Malaysia. Prashant Kumar acknowledges the 446 support received from the Research England funding under the Global Challenge Research Fund 447 (GCRF) programme for the CArE-Cities (Clean Air Engineering for Cities) project. KNA Maulud 448 acknowledges research supports from UKM Dana Impak Perdana, DIP-2018-030.

\section{$450 \quad$ Conflict of Interest}

451 The authors declare no financial competing interests. 
Aldrian E, Dwi Susanto R. Identification of three dominant rainfall regions within Indonesia and their relationship to sea surface temperature. International Journal of Climatology 2003; 23: 1435-1452.

Blake D, Hinwood AL, Horwitz P. Peat fires and air quality: Volatile organic compounds and particulates. Chemosphere 2009; 76: 419-423.

Brauer M, Freedman G, Frostad J, van Donkelaar A, Martin RV, Dentener F, et al. Ambient Air Pollution Exposure Estimation for the Global Burden of Disease 2013. Environmental Science \& Technology 2016; 50: 79-88.

Cohen AJ, Brauer M, Burnett R, Anderson HR, Frostad J, Estep K, et al. Estimates and 25-year trends of the global burden of disease attributable to ambient air pollution: an analysis of data from the Global Burden of Diseases Study 2015. The Lancet 2017; 389: 1907-1918.

EDGAR. European Commission, Joint Research Centre (EC-JRC)/Netherlands Environmental Assessment Agency (PBL). Emissions Database for Global Atmospheric Research (EDGAR), release EDGAR v4.3.2 (1970 - 2012) of March 2016, http://edgar.jrc.ec.europa.eu. 2016.

Field RD, van der Werf GR, Fanin T, Fetzer EJ, Fuller R, Jethva H, et al. Indonesian fire activity and smoke pollution in 2015 show persistent nonlinear sensitivity to El Niño-induced drought. Proceedings of the National Academy of Sciences 2016; 113: 9204-9209.

Friedlander SK. Smoke, dust and haze: fundamentals of aerosol dynamics. Second Edition, Oxford University Press, New York. 2000.

Gaveau DLA, Sheil D, Husnayaen, Salim MA, Arjasakusuma S, Ancrenaz M, et al. Rapid conversions and avoided deforestation: examining four decades of industrial plantation expansion in Borneo. Scientific Reports 2016; 6: 32017.

Geng F, Tie X, Guenther A, Li G, Cao J, Harley P. Effect of isoprene emissions from major forests on ozone formation in the city of Shanghai, China. Atmos. Chem. Phys. 2011; 11: 10449-10459.

Hope G, Chokkalingam U, Anwar S. The Stratigraphy and Fire History of the Kutai Peatlands, Kalimantan, Indonesia. Quaternary

Research 2005; 64: 407-417.

$\mathrm{Hu}$ Y, Fernandez-Anez N, Smith TEL, Rein G. Review of emissions from smouldering peat fires and their contribution to regional haze episodes \%J International Journal of Wildland Fire. 2018; 27: 293-312.

Jayarathne T, Stockwell CE, Gilbert AA, Daugherty K, Cochrane MA, Ryan KC, et al. Chemical characterization of fine particulate matter emitted by peat fires in Central Kalimantan, Indonesia, during the 2015 El Niño. Atmos. Chem. Phys. Discuss. 2017; 2017: 1-47.

Jong HN. Indonesia forest-clearing ban is made permanent, but labeled 'propaganda' Mongabay, 2019. 
Keywood MD, Ayers GP, Gras JL, Boers CP, Leong. Haze in the Klang Valley of Malaysia. Atmos. Chem. Phys. 2003; 3: 591-605.

Khan F, Latif MT, Juneng L, Amil N, Mohd Nadzir MS, Syedul Hoque HM. Physicochemical factors and sources of particulate matter at residential urban environment in Kuala Lumpur. Journal of the Air \& Waste Management Association 2015; 65: 958-969.

Khan MF, Maulud KNA, Latif MT, Chung JX, Amil N, Alias A, et al. Physicochemical factors and their potential sources inferred from long-term rainfall measurements at an urban and a remote rural site in tropical areas. Science of The Total Environment 2018; 613-614: 1401-1416.

Khan MF, Sulong NA, Latif MT, Nadzir MSM, Amil N, Hussain DFM, et al. Comprehensive assessment of PM2.5 physicochemical properties during the Southeast Asia dry season (southwest monsoon). Journal of Geophysical Research: Atmospheres 2016; 121: 2016JD025894.

Koe LCC, Arellano AF, McGregor JL. Investigating the haze transport from 1997 biomass burning in Southeast Asia: its impact upon Singapore. Atmospheric Environment 2001; 35: 2723-2734.

Kumar A, Bali K, Singh S, Naja M, Mishra AK. Estimates of reactive trace gases (NMVOCs, $\mathrm{CO}$ and $\mathrm{NOx}$ ) and their ozone forming potentials during forest fire over Southern Himalayan region. Atmospheric Research 2019; 227: 41-51.

Kumar P, Adelodun AA, Khan MF, Krisnawati H, Garcia-Menendez F. Towards an improved understanding of greenhouse gas emissions and fluxes in tropical peatlands of Southeast Asia. Sustainable Cities and Society 2020; 53: 101881.

Kumar P, Khare M, Harrison RM, Bloss WJ, Lewis AC, Coe H, et al. New directions: Air pollution challenges for developing megacities like Delhi. Atmospheric Environment 2015; 122: 657-661.

Langmann B, Duncan B, Textor C, Trentmann J, Werf GRvd. Vegetation fire emissions and their impact on air pollution and climate. Atmospheric Environment 2009; 43: $107-116$.

Malaysia-DOE. Chronology of Haze Episodes in Malaysia. Official Portal of Department of Environment Malaysia, 2019a.

Malaysia-DOE. Chronology of Haze Episodes in Malaysia. Official Portal of Department of Environment Malaysia. 2019b.

Monks PS, Archibald AT, Colette A, Cooper O, Coyle M, Derwent R, et al. Tropospheric ozone and its precursors from the urban to the global scale from air quality to short-lived climate forcer. Atmos. Chem. Phys. 2015; 15: 8889-8973.

NOAA. The El Niño Southern Oscillation (ENSO) is one of the most important climatic phenomena on Earth. 2019. National Oceanic Atmospheric Administration, National Oceanic Atmospheric Administration, 2015.

Pakiam GK. Agriculture in Johor: What's Left? Yusof Ishak Institute, Yusof Ishak Institute, Singapore, 2018. 
Roulston C, C. PW, L. STE, É. - A. G, S. E, M. YC, et al. Fine Particle Emissions From Tropical Peat Fires Decrease Rapidly With Time Since Ignition. Journal of Geophysical Research: Atmospheres 2018; 123.

Samsuddin NAC, Khan MF, Maulud KNA, Hamid AH, Munna FT, Rahim MAA, et al. Local and transboundary factors' impacts on trace gases and aerosol during haze episode in 2015 El Niño in Malaysia. Science of The Total Environment 2018; 630: 1502-1514.

Seinfeld JH, Pandis SN. Atmospheric chemistry and physics: from air pollution to climate change: John Wiley \& Sons, 2016.

Stein AF, Draxler RR, Rolph GD, Stunder BJB, Cohen MD, Ngan F. NOAA's HYSPLIT Atmospheric Transport and Dispersion Modeling System. Bulletin of the American Meteorological Society 2015; 96: 2059-2077.

Stockwell CE, Jayarathne T, Cochrane MA, Ryan KC, Putra EI, Saharjo BH, et al. Field measurements of trace gases and aerosols emitted by peat fires in Central Kalimantan, Indonesia, during the 2015 El Niño. Atmos. Chem. Phys. 2016; 16: 11711-11732.

Stockwell CE, Veres PR, Williams J, Yokelson RJ. Characterization of biomass burning emissions from cooking fires, peat, crop residue, and other fuels with highresolution proton-transfer-reaction time-of-flight mass spectrometry. Atmos. Chem. Phys. 2015; 15: 845-865.

Underwood E. The polluted brain. Science 2017; 355: 342-345.

Varkkey H. The Haze Problem in Southeast Asia Palm Oil and Patronage, 1st Edition. New York: Routledge, 2016.

Wennberg PO, Bates KH, Crounse JD, Dodson LG, McVay RC, Mertens LA, et al. Gas-Phase Reactions of Isoprene and Its Major Oxidation Products. Chemical Reviews 2018; 118: 3337-3390.

WHO. WHO global urban ambient air pollution database (update 2016). 2016.

WHO. 9 out of 10 people worldwide breathe polluted air, but more countries are taking action., 2018.

Wooster M, Gaveau D, Salim M, Zhang T, Xu W, Green D, et al. New Tropical Peatland Gas and Particulate Emissions Factors Indicate 2015 Indonesian Fires Released Far More Particulate Matter (but Less Methane) than Current Inventories Imply. Remote Sensing 2018; 10: 495.

Wooster MJ, Roberts G, Perry GLW, Kaufman YJ. Retrieval of biomass combustion rates and totals from fire radiative power observations: FRP derivation and calibration relationships between biomass consumption and fire radiative energy release. Journal of Geophysical Research: Atmospheres 2005; 110.

Yokelson RJ, Susott R, Ward DE, Reardon J, Griffith DWT. Emissions from smoldering combustion of biomass measured by open-path Fourier transform infrared spectroscopy. 1997; 102: 18865-18877.

Zhai P, Yu R, Guo Y, Li Q, Ren X, Wang Y, et al. The strong El Niño of 2015/16 and its dominant impacts on global and China's climate. 2016; 30: 283-297. 


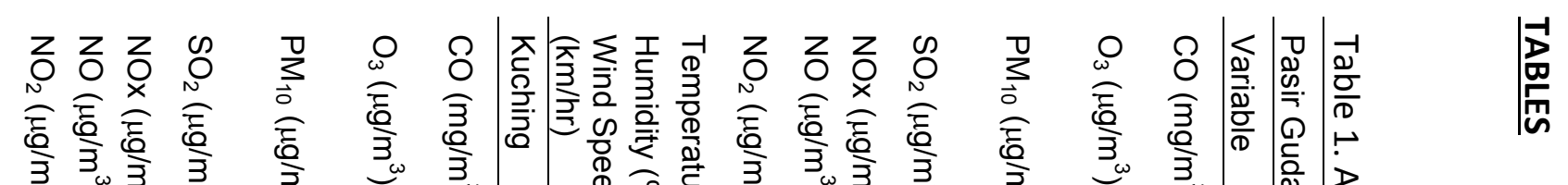

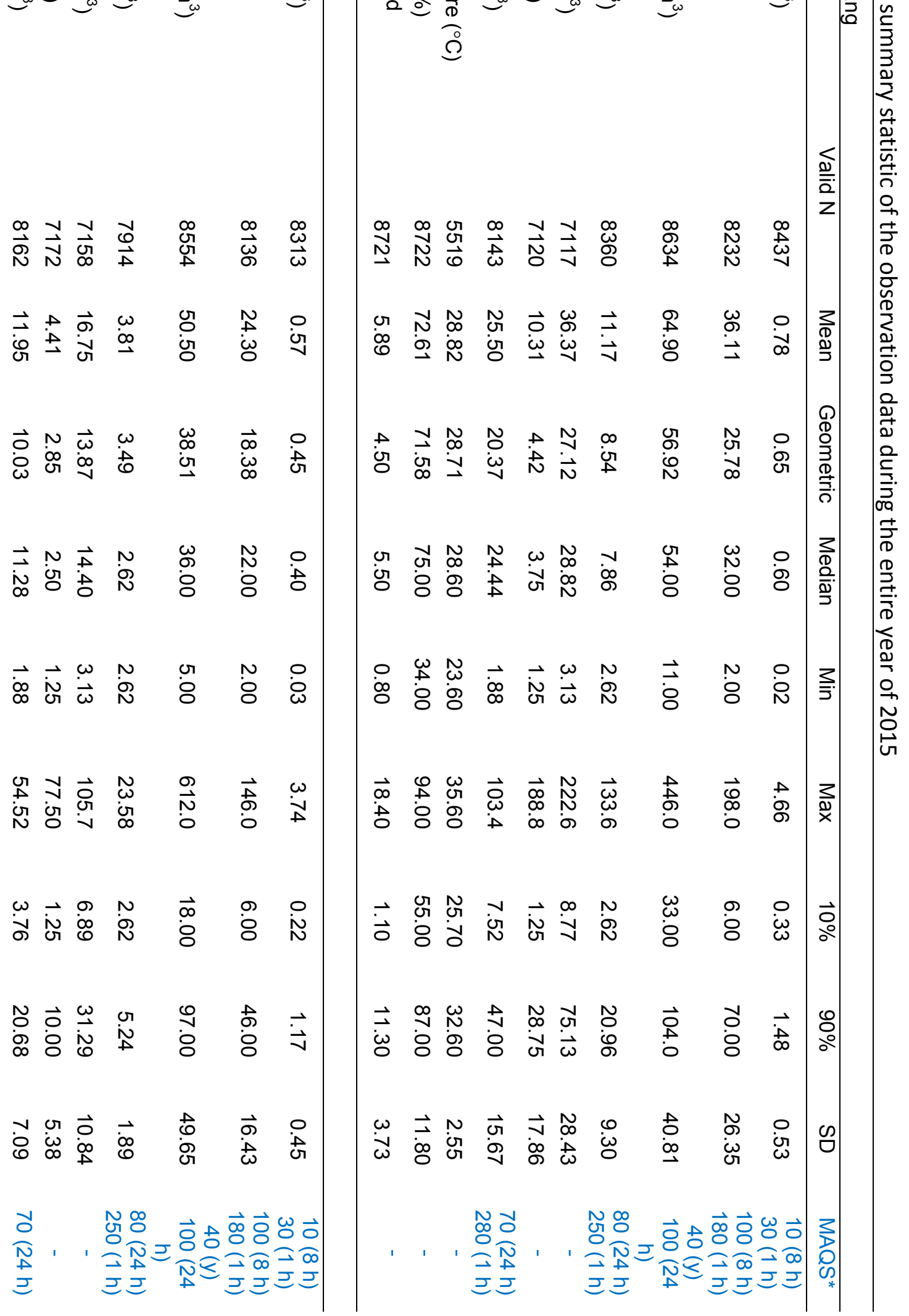




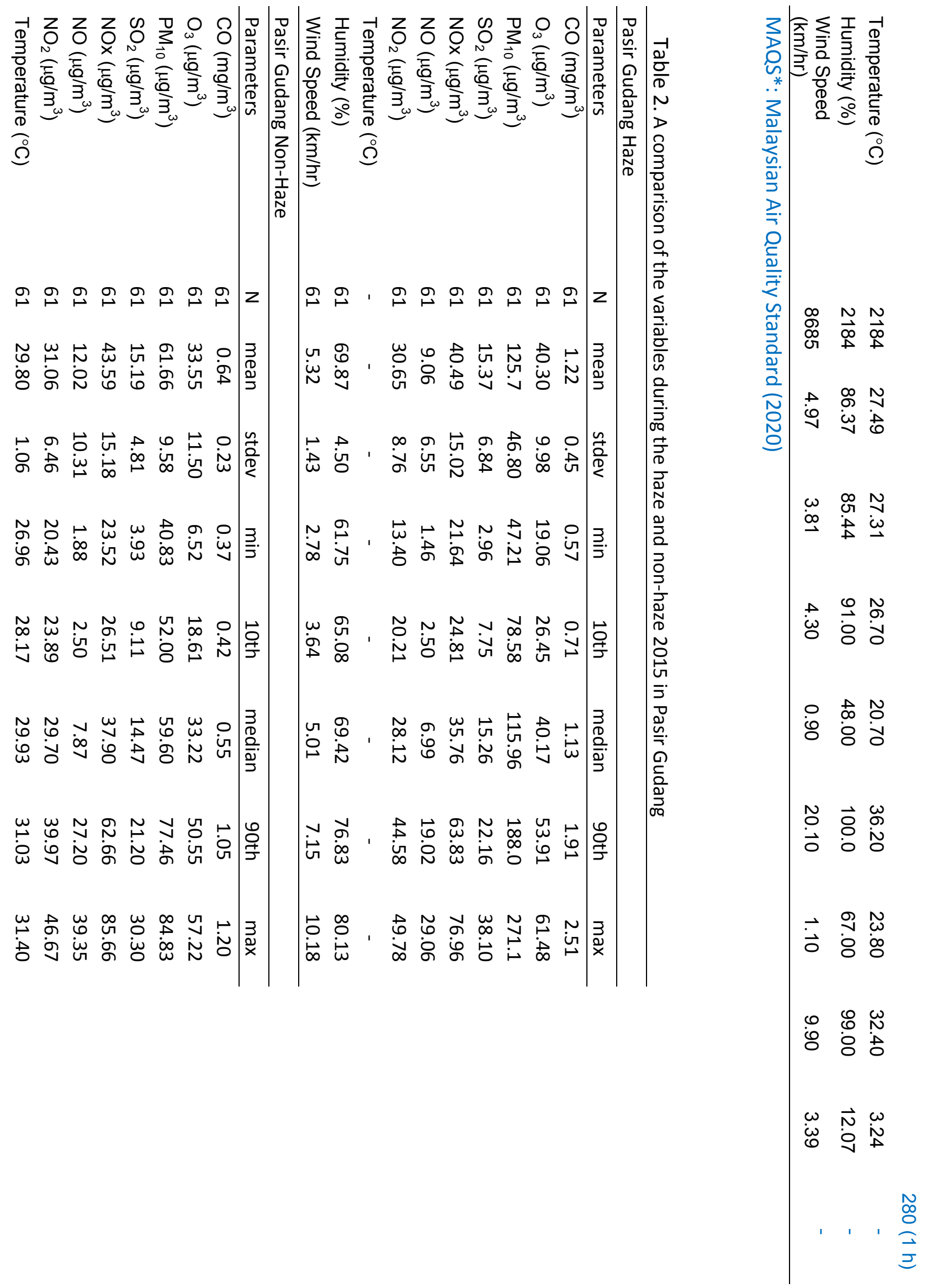




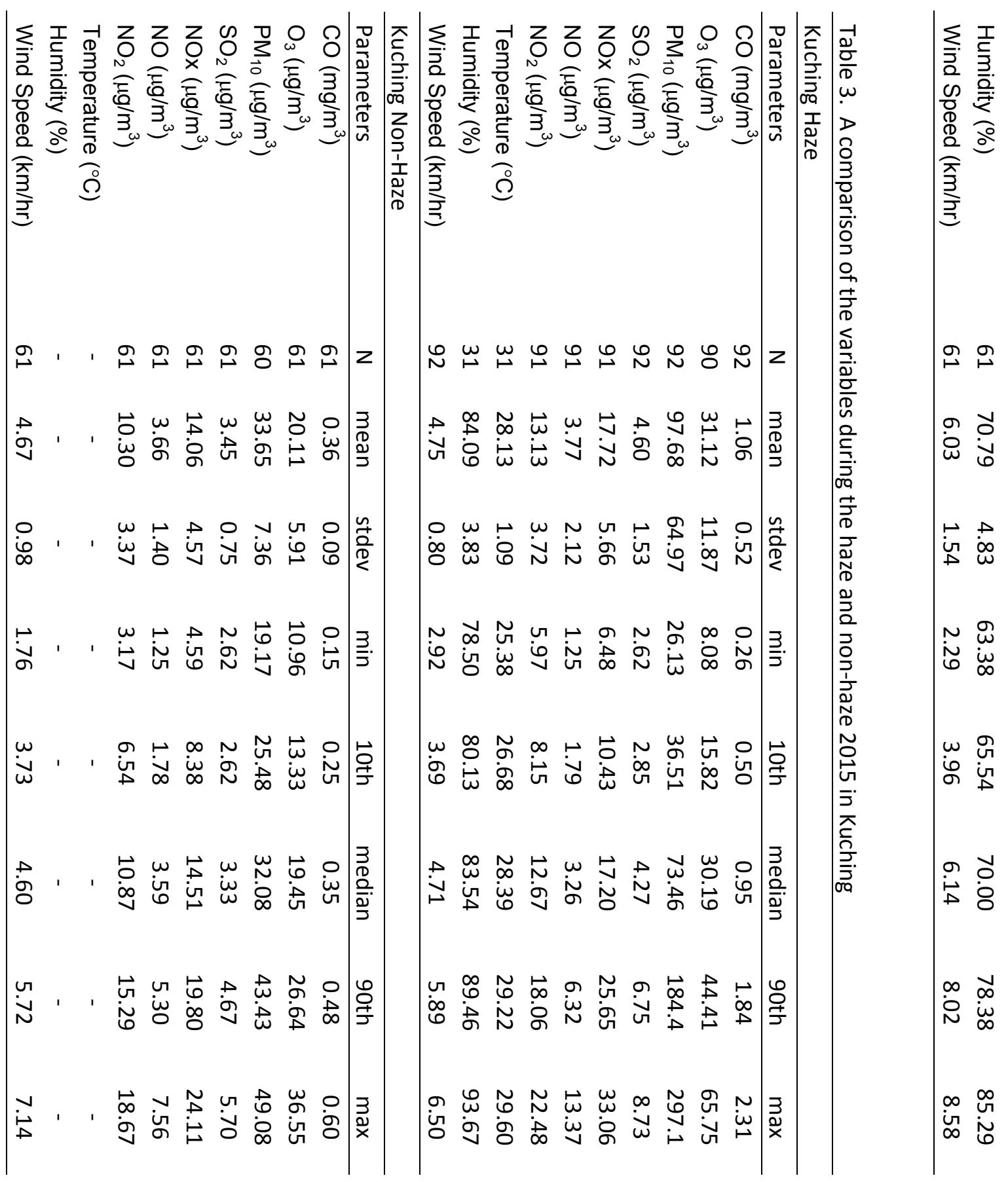



Figures' captions

Figure 1. Total aerosol optical depth (AOD) during non-haze and haze period over Southeast Asia in 2015 (assimilated Tera/Aqua MODIS AOD received from CAMS in the ECMWF website)

Figure 2. Transport of air mass over a Southern Peninsular site in Malaysia in 2015. Percentage frequency of each cluster. January (c1(30\%), c2(70\%)), February (c1(69\%), c2(31\%)), March (c1(61\%), c2(39\%)), April(c1(40\%), c2(60\%)), May (c1(85\%), c2(15\%), June (c3(36\%), c2(64\%)), July (c1(55\%), c2(45\%)), August (c1(75\%), c2(25\%)), September (c1(10\%), c2(90\%)), October (c1(37\%), c2(63\%)), November (c1(58\%), c2(42\%)) and December (c1(19\%), c2(71\%), c3(10\%))

Figure 3. Transport of air mass over a Borneo site in Malaysia in 2015. Percentage frequency of each cluster. January (c1(12\%), c2(88\%)), February (c1(59\%), c2(41\%)), March (c1(67\%), c2(33\%)), April(c1(56\%), c2(44\%)), May (c1(26\%), c2(27), c3(47)), June (c1(33), c2(23), c3(44\%)), July (c1(39\%), c2(61)), August (c1(46\%), c2(37\%), c3(17\%)), September (c1(41), c2(6\%), c3(46\%)), October (c1(32\%), c2(62\%), c3(6\%)), November (c1(35\%), c2(58\%), c3(7\%)) and December (c1(22\%), c2(65\%), c3(12\%))

Figure 4. Daily variation of aerosols and reactive gases in a Southern Peninsular site in Malaysia in 2015 (annotated Malaysian air quality standard values)

Figure 5 Daily variation of aerosols and reactive gases in a Borneo site in Malaysia in 2015 (annotated Malaysian air quality standard values)

Figure 6. Assimilated Flux of BC during the wild forest fires in 2015 over the Southeast Asia Figure 7. Assimilated Flux of CO during the wild forest fires in 2015 over the Southeast Asia

Figure 8. Emission flux of $\mathrm{CO}$ and planetary boundary layer $(\mathrm{m})$ received from GFAS in West Kalimantan and Sumatra in 2015 

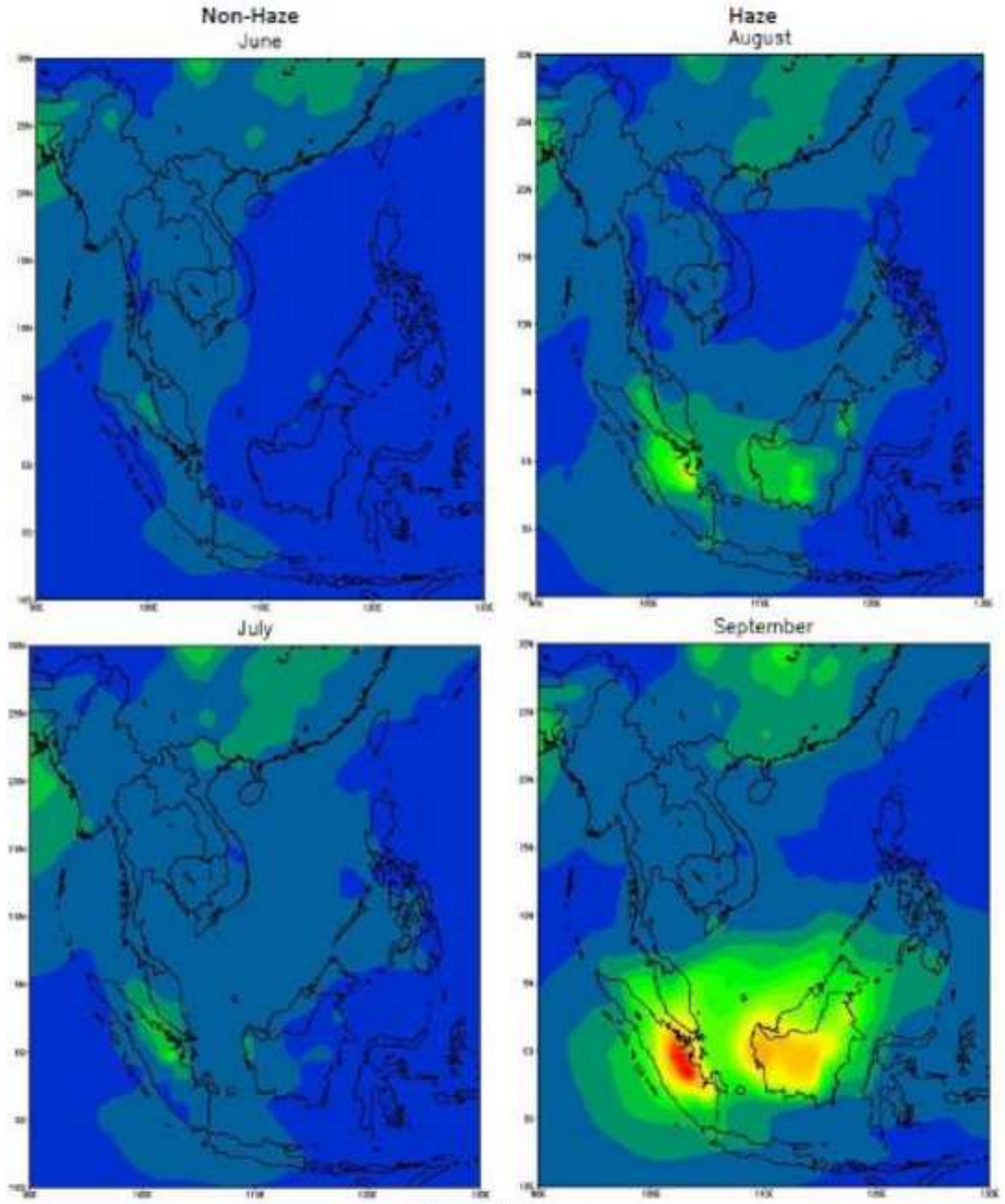

AOD $550 \mathrm{~nm}$

$00.20 .40 .60 .8 \quad 1 \quad 1.21 .41 .61 .822 \quad 2.22 .42 .62 .833 .23 .43 .63 .84$ 
Click here to download high resolution image
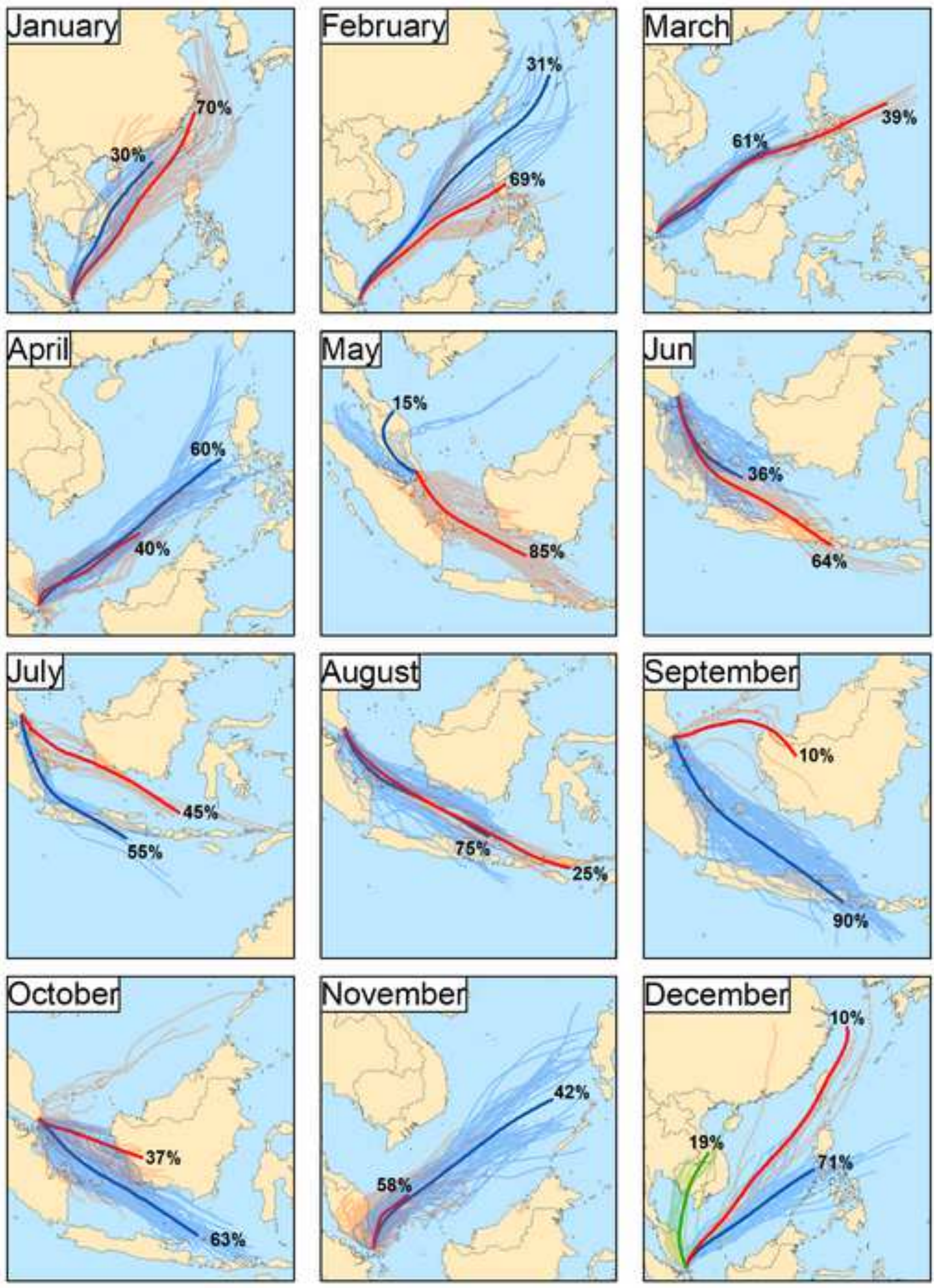
Click here to download high resolution image
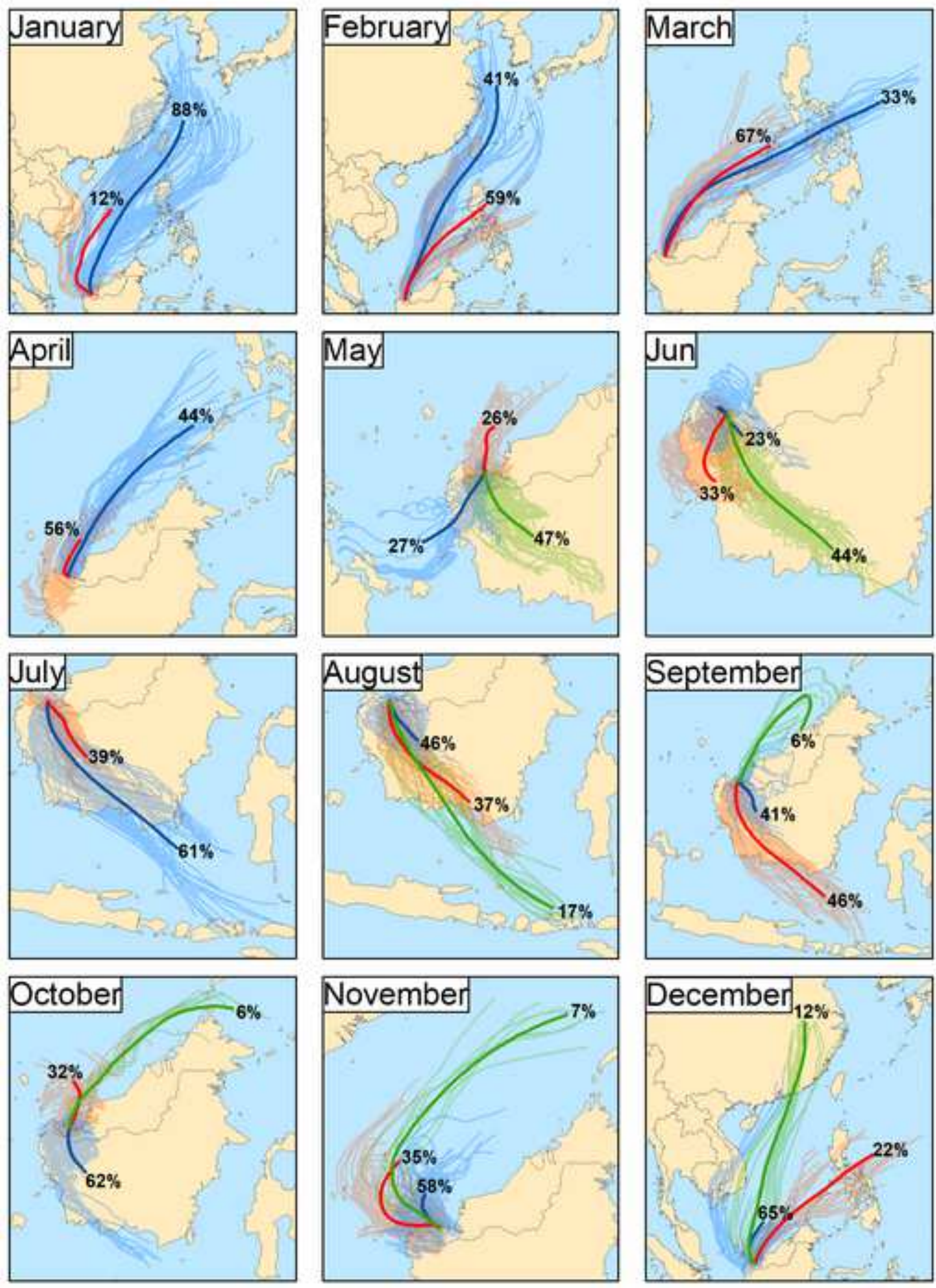

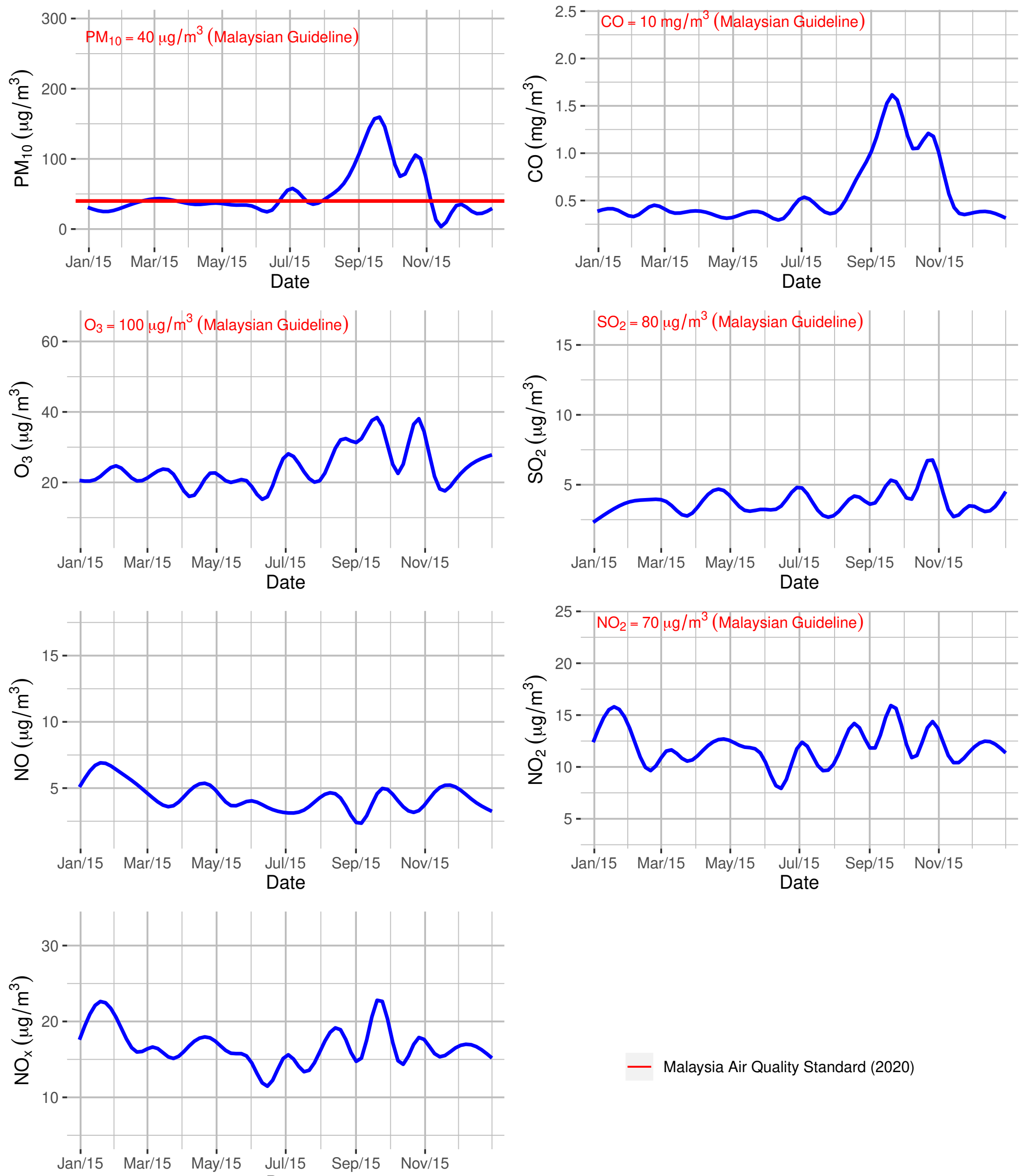
Jan
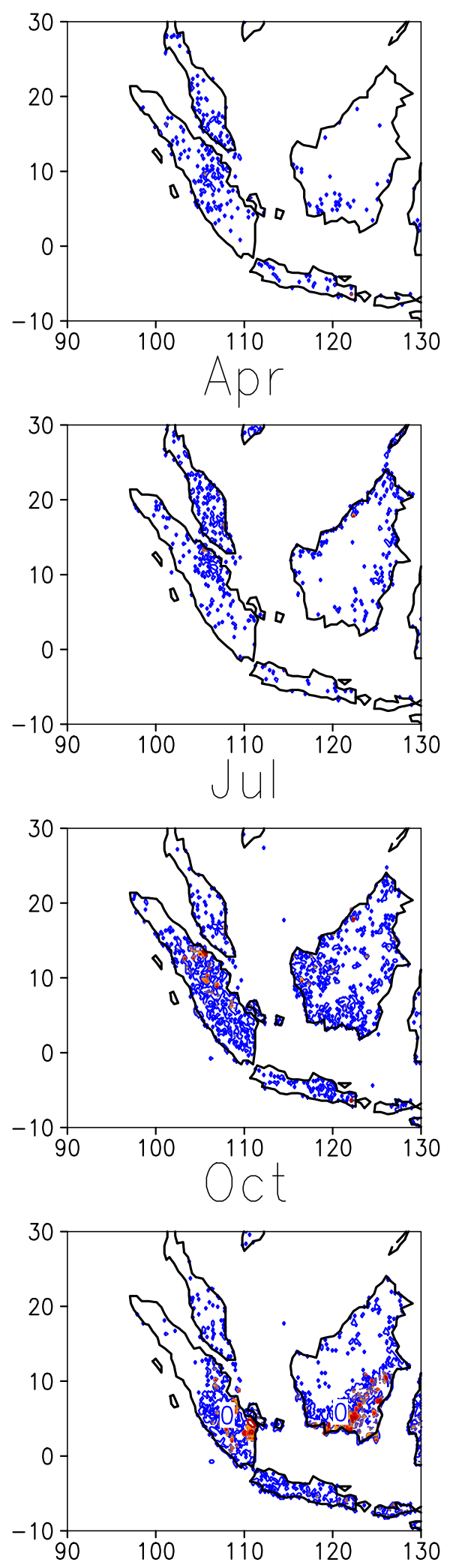

Feb
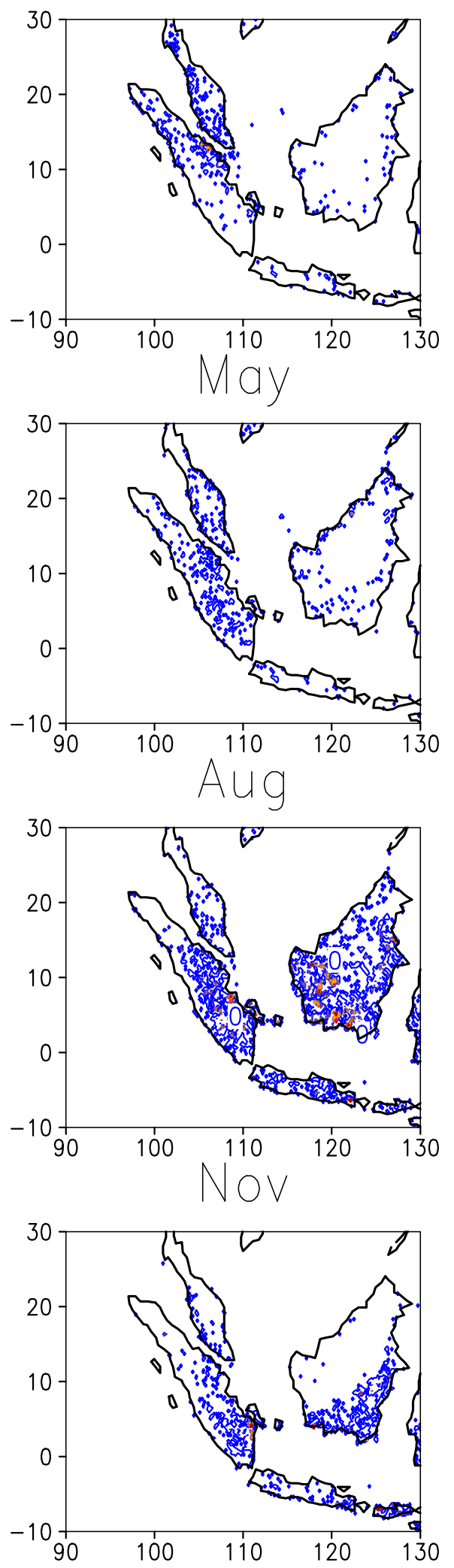

Mar
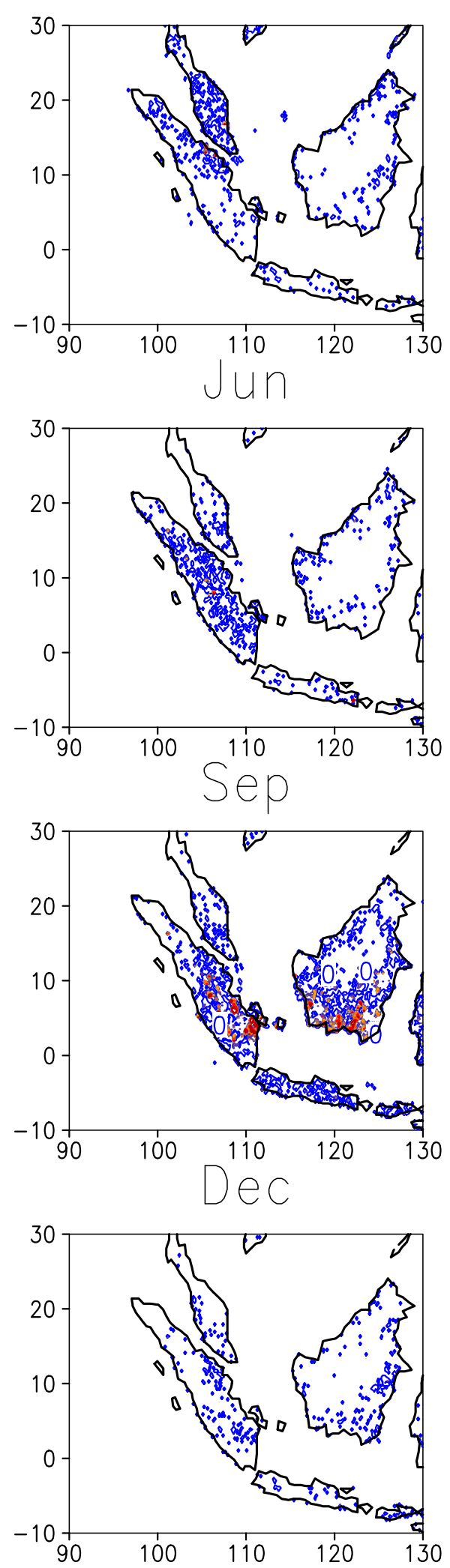

$B C$ Flux fire $\left(\mathrm{kg} / \mathrm{m}^{\wedge} 2 / \mathrm{s}\right)$ 
Jan
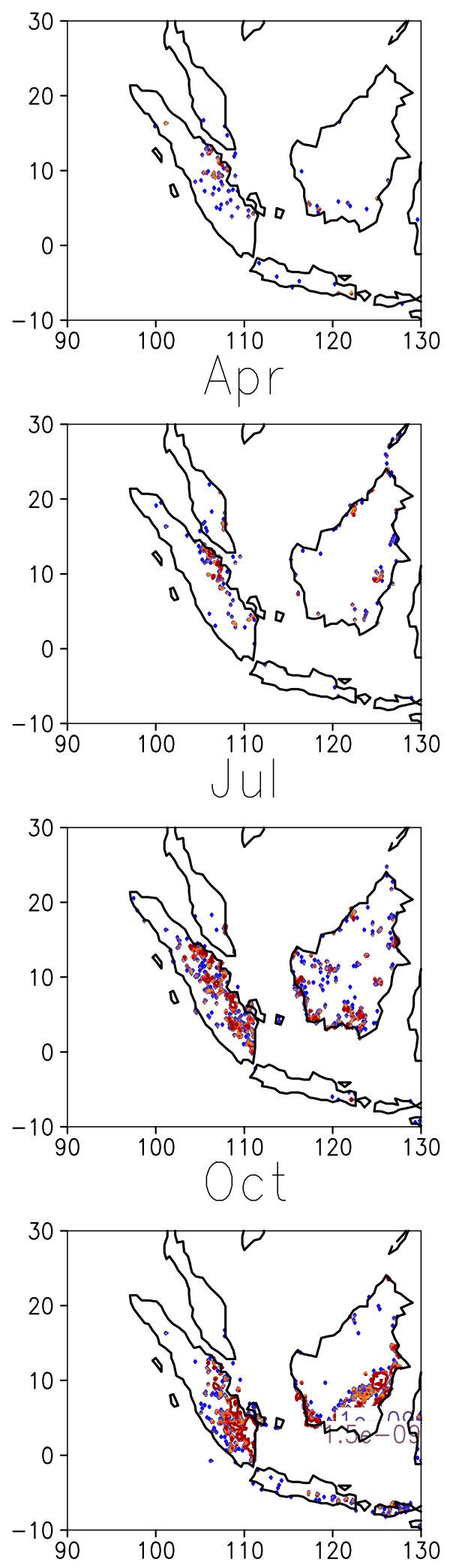

Feb
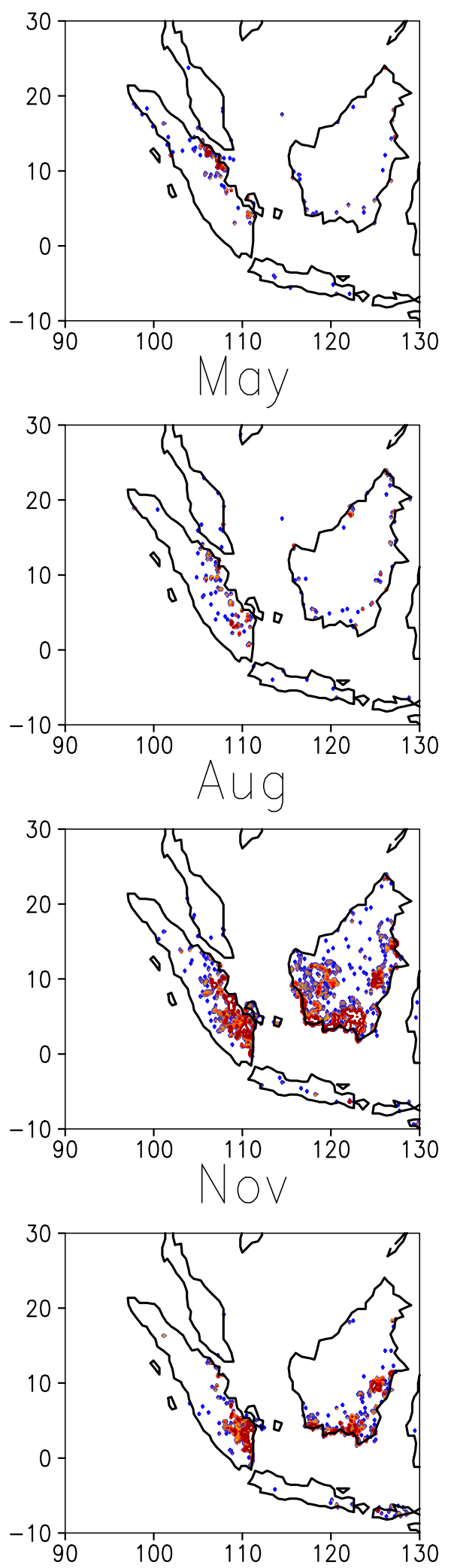

Mar
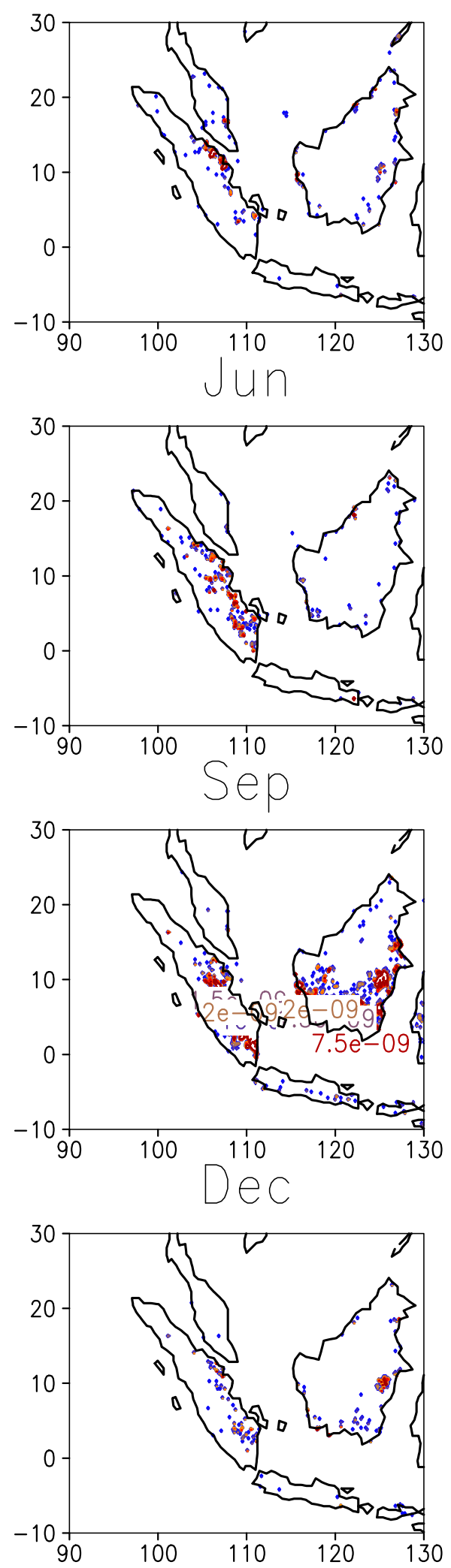

Fire CO Flux $\left(\mathrm{kg} / \mathrm{m}^{\wedge} 2 / \mathrm{s}\right)$ 

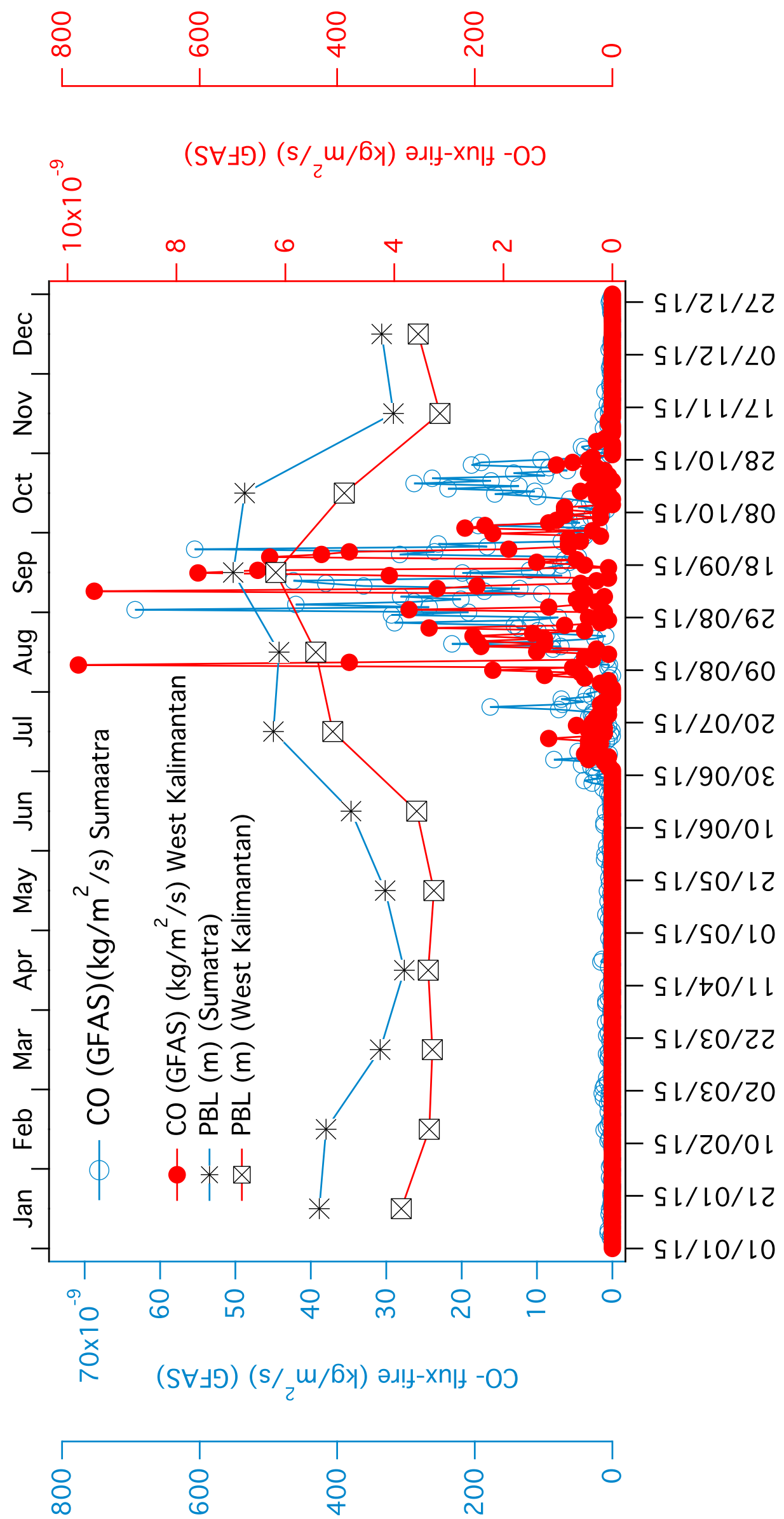

(eגłeuns) (m) าดd 